\title{
THE ROLE OF ONLINE INFORMATION SOURCES IN PROMOTING BANJALUKA CITY BRAND: REPORT ON THE MAIN TARGET GROUPS BY COUNTRY OF ORIGIN
}

\author{
Sanja Božicín, \\ Milan Ivkov', \\ Ivana Blešić1, \\ Nemanja Milenković ${ }^{2}$ \\ ${ }^{1}$ Faculty of Sciences, \\ University of Novi Sad, Serbia \\ ${ }^{2}$ Faculty of Technical \\ Sciences, \\ University of Novi Sad, Serbia
}

\begin{abstract}
:
Despite the immense role of online information sources in destination promotion, many DMOs (Destination Management Organization) are still not using it in an adequate way. This especially refers to tourist destinations which are still in their initial tourism development phases. The main aim of the paper was to analyze what information sources certain target groups use to get informed about Banja Luka city brand and how dominant are websites, social media and other online information sources. The study was conducted during September - December 2017 and included the total of 504 respondents from four countries: Bosnia and Herzegovina, Serbia, Croatia and Slovenia. The sample included respondents who have visited and those who have never visited Banja Luka. The analysis shows that Word-of-mouth, Website of the tourist destination, and Facebook are the most frequently used information sources by all analyzed respondents. Also, it is confirmed that online sources are more dominate than the traditional one. This is an exception only in case of Twitter which showed to be very rarely used to get informed about this destination. The study indicates certain differences between analyzed countries which are discussed in the paper.
\end{abstract}

\section{Keywords:}

online information sources, destination marketing, city branding, Banja Luka.

\section{INTRODUCTION}

Today, the Internet has become the main information source used by tourists, important in all travel stages, but especially in decision-making [1]. It provides tourists with information, photographs and video clips of the destination, as well as descriptions, comments, impressions and ratings that other tourists give after the visit [2]. Moreover, in most cases, it is a free tool for the tourism promotion of tourist destinations. This especially refers to promotion on social networks which approaches lot of people and usually is free of charge. Consequently, traditional forms of promotion and marketing activities became less influential and are being replaced with contemporary ones such as websites, online travel guides, social network sites etc. [3, 4]. Furthermore, apart from traditional word-of-mouth, electronic word-of-mouth has been developing rapidly in recent years and becoming important information source about travel destinations $[5,6,7]$. The particular popularity have the e-mail:

sanja.bozic@dgt.uns.ac.rs 
social media websites as forms of consumer-generated content (CGC) such as blogs, virtual communities, wikis, social networks, media files shared on sites like YouTube (video sharing) and Instagram (photo sharing), Microblogging (Twitter), video-sharing (Youtube, Vevo), photosharing (Flicker, Instagram), travel-specific websites (Tripadvisor) and travel communities (Travellerspoint), which are now major tools in the travelers' decision process $[8,9]$.

Moreover, the websites and social media of Destination Management Organizations (DMOs) are among the most useful tools for creating and enhancing destination brand and image [10]. The main advantage of using Internet for such purposes is certainly the ability to customize the information DMOs provide, and maintain the direct contact with tourists [11]. Also, websites and social media today allow consumers to "experience" destinations and its attractions before they even visit it [12]. This consequently leads to an image creation [13]. Nevertheless, not many DMOs have realized the importance of using online information tools for creating brand awareness and attracting visits, and their use of such content is still experimental $[14,15,16]$. This is especially true in case of tourist destinations with emerging destination brand, such as Banja Luka city. Although Banja Luka is the second largest city in Bosnia and Herzegovina, it is the seventh according to tourist visits. In 2016, it was visited by 82171 tourists and had 130790 nights with Serbian, Croatian and Slovenian tourists being the most dominant [17]. Besides domestic tourist, these three countries represent the main target groups of Banja Luka by country of origin. Thus, the main aim of the paper was to explore what information sources these target groups (by country of origin) used to get informed about Banja Luka city brand and how dominant are the website, social media and other online information sources (especially social network sites). The main assumption is that the online information sources will be more dominant than traditional ones, although Banja Luka online marketing is still in its initial phases. Moreover, the study intends to compare the information sources used by respondents from different analyzed countries in order to determine whether there are some larger differences. The study is based on the assumption that city marketing should be based on the analysis of the dominant information sources on particular tourist market in order to ensure that the message is approaching potential tourist through the appropriate communication channels. This should be a part of regular research conducted by DMOs or other subjects dealing with destination marketing.

\section{METHODOLOGY}

Sample

The sample consists of 504 respondents. The sample was collected in four countries and is relatively evenly distributed: Bosnia and Herzegovina (110 respondents), Serbia (131 respondents) Croatia (138 respondents) and Slovenia (125 respondents). There are $31 \%$ of male and $69 \%$ of female respondents, while the average age of the sample is 31.51 years (Std. 10.078). The respondents with higher education (college, bachelor, master or Ph.D.) are dominant and represent $76 \%$ of the total sample. The majority of respondents are employed and with an average monthly income. In terms of frequency of traveling, there are a great number of those who travel several times a year.

\begin{tabular}{|c|c|c|}
\hline Variable & Options & Total (\%) \\
\hline \multirow{2}{*}{ Gender (\%) } & Man & 31 \\
\hline & Women & \\
\hline \multirow{2}{*}{ Age (years) } & Average age and & 31.51 \\
\hline & Std. deviation & Std. 10.078 \\
\hline \multirow{4}{*}{ Country } & Serbia & 26 \\
\hline & Bosnia and Herzegovina & 21.82 \\
\hline & Slovenia & 24.80 \\
\hline & Croatia & 27.38 \\
\hline \multirow{6}{*}{$\begin{array}{l}\text { Education } \\
(\%)\end{array}$} & Elementary school & 0.2 \\
\hline & Secondary school & 23.8 \\
\hline & Higher school & 8.3 \\
\hline & Bachelor degree & 46.4 \\
\hline & Master degree & 13.1 \\
\hline & $\mathrm{PhD}$ & 8.1 \\
\hline \multirow{4}{*}{$\begin{array}{l}\text { Employment } \\
\text { Status (\%) }\end{array}$} & Student/pupil & 32.7 \\
\hline & Employed & 60.5 \\
\hline & Unemployed & 5 \\
\hline & Retired & 1.8 \\
\hline \multirow{3}{*}{$\begin{array}{l}\text { Monthly } \\
\text { income (\%) }\end{array}$} & Bellow average & 22.2 \\
\hline & Average & 50.4 \\
\hline & Above average & 27.4 \\
\hline \multirow{5}{*}{$\begin{array}{l}\text { The } \\
\text { frequency } \\
\text { of traveling } \\
(\%)\end{array}$} & Several times a month & 7.9 \\
\hline & Once a month & 10.1 \\
\hline & Several times a year & 57.3 \\
\hline & Once a year & 20.8 \\
\hline & Once in several years & 3.8 \\
\hline \multirow{3}{*}{$\begin{array}{l}\text { Have you } \\
\text { ever visited } \\
\text { Banja Luka? } \\
\text { (\%) }\end{array}$} & Never & \\
\hline & Yes, once & 21.1 \\
\hline & Yes, several times & 36.5 \\
\hline
\end{tabular}

Table 1. Sociodemographic profile of respondents 
The sample consists of potential tourists who have never been to Banja Luka (42.5\%), but also those who have visited Banja Luka at least ones (57.5\%). From the four analyzed countries, the largest number of Croatian respondents $(71.7 \%)$ has never been to Banja Luka city.

\section{Instruments}

This study regarding the role of particular information sources about Banja Luka city brand was part of the larger study on city brand perception of Banja Luka. For this study, two parts of the questionnaire were used. First part is related to sociodemographic characteristics of respondents (gender, age, education, and the question related to whether they have visited the city of Banja Luka. The main part of the questionnaire referred to information sources they used to get informed about Banja Luka and its city brand. The total of 12 answers including online and offline information sources was offered and respondents could choose multiple answers.

\section{Procedure}

The research was conducted by combining a standard pen and paper questionnaire and Google form online survey during September-December, 2017. The respondents were informed of the general purpose of the study and that participation is voluntary and anonymous. The sample was collected in four countries Serbia, Croatia, Slovenia and Bosnia and Herzegovina.
Those countries were chosen as they represent countries which are the main target groups of Banja Luka city (according to Republika Srpska Institute of Statistics, 2017 the largest number of tourists in Banja Luka come from these countries). By using pen and paper survey 220 respondents were approached while the rest was collected by the online survey (which was shared via emails and Facebook). Moreover, the online survey was shared at the official Banja Luka Facebook page.

\section{Data analysis}

Obtained data were processed in SPSS version 20, by using descriptive statistics and frequency analysis.

\section{RESULTS AND DISCUSSION}

As mentioned before, data on which information sources our target groups usually use to get informed about tourist destination is quite important in managing the process of creating brand awareness. The main aim of this study was to analyze whether there is a difference between sources of information the respondents from Serbia, Bosnia and Herzegovina, Slovenia and Croatia used in order to get informed about Banja Luka city. The results are compared and shown in Table 2. Firstly, the results show that online sources of information are used more frequently to get informed about Banja Luka as a tourist destination. The most dominant is certainly the websites and social network sites.

\begin{tabular}{|c|c|c|c|c|c|}
\hline $\begin{array}{l}\text { Information sources about } \\
\text { Banja Luka city brand }\end{array}$ & Serbia & $\begin{array}{l}\text { Bosnia and } \\
\text { Herzegovina }\end{array}$ & Slovenia & Croatia & $\begin{array}{l}\text { Whole } \\
\text { sample }\end{array}$ \\
\hline Website of the tourist destination & $71 \%$ & $81 \%$ & $88 \%$ & $54 \%$ & $73 \%$ \\
\hline Social networks (Facebook) & $62 \%$ & $70 \%$ & $50 \%$ & $51 \%$ & $58 \%$ \\
\hline Social networks (Instagram) & $36 \%$ & $26 \%$ & $31 \%$ & $24 \%$ & $29 \%$ \\
\hline Social networks (Twitter) & $0 \%$ & $0 \%$ & $6 \%$ & $3 \%$ & $2 \%$ \\
\hline Youtube & $32 \%$ & $32 \%$ & $47 \%$ & $22 \%$ & $33 \%$ \\
\hline Via travel agencies & $27 \%$ & $39 \%$ & $20 \%$ & $13 \%$ & $24 \%$ \\
\hline Through tourism fairs & $15 \%$ & $23 \%$ & $21 \%$ & $9 \%$ & $16 \%$ \\
\hline Through specialized journals & $3 \%$ & $3 \%$ & $6 \%$ & $7 \%$ & $5 \%$ \\
\hline Through brochures and other printed material & $15 \%$ & $25 \%$ & $19 \%$ & $14 \%$ & $18 \%$ \\
\hline Via online travel guides & $7 \%$ & $6 \%$ & $17 \%$ & $19 \%$ & $13 \%$ \\
\hline Via Tripadviser & $26 \%$ & $23 \%$ & $31 \%$ & $21 \%$ & $25 \%$ \\
\hline Through family / friends (word-of-mouth) & $85 \%$ & $86 \%$ & $54 \%$ & $64 \%$ & $72 \%$ \\
\hline
\end{tabular}

Table 2. Information sources about Banja Luka in four analyzed countries 
The analysis shows that Word-of-mouth, Website of the tourist destination, and Facebook are the most frequently used information sources by all analyzed respondents. Word-of-mouth has proved to be a dominant source of information about destination brand in many previous studies $[18,19]$.

In connection to this, it is interesting to mention the study on tourism potentials of Banja Luka city brand done by City of Banja Luka (2017), which emphasizes the importance of better CEO optimization of Banja Luka official website, which is important information source about the city (also confirmed by the results of this study). In the mentioned study, they conducted the search by keywords Banja Luka, Kastel Banja Luka and Vrbas Banja Luka. Namely, in the first 10 search results, there are mostly websites of administrative services of the city, Wikipedia or the restaurant Kazamat on Kastel. Also, the search results show that the websites for hotel booking (booking.com), or travel recommendation sites such as tripadvisor.com or visitmycountry.com and banjaluka360.com. Even the page dedicated to the promotion of tourism in Bosna and Herzegovina (bhtourism. $b a$ ) is shown before some of the city's websites promoting tourism in Banja Luka.

Apart from Facebook and the official website, Youtube, Instagram and Tripadvisor are quite frequently used to get information about Banja Luka. On the other hand, Twitter, specialized journals and online travel guides are the least dominant.

When comparing online information sources to traditional sources of information it is evident that the online media are much more influential in creating brand awareness for all analyzed target groups. On the other hand, there are also some differences in individual information sources used by different target groups. For instance, for respondents from Serbia and Bosnia and Herzegovina, word-of-mouth is the most dominant source of information about Banja Luka city brand. This is quite expected to find as many people from Serbia and especially other parts of Bosnia and Herzegovina have many friends, cousins and family members living in Banja Luka representing the important source of information about Banja Luka city's attractions. Besides this, the website and Facebook are also very important sources of information. The word-of-mouth is an important source for all respondents, but at least for Slovenian respondents, which could be because Slovenia is far away from Banja Luka and not many Slovenian people live in the city. For Slovenian respondents, the website of Banja Luka city, Facebook and Youtube are the most dominant sources of information, so they rely on the online promotion. When compared to the other target groups, Youtube and Tripadvisor are most commonly used by Slovenian respondents. As mentioned before, Tripadvisor results are also one of the first results of the search on Banja Luka city tourism. Also, more than other groups, respondents from Bosnia and Herzegovina used Facebook, travel agencies and brochures and other printed material. This may be because printed materials and travel agencies offering Banja Luka city break are the most available in Bosnia and Herzegovina, while on contrary to Slovenia, travel agencies rarely offer Banja Luka city break. In terms of respondents from Croatia, the online information sources are also predominant, as Banja Luka is rarely offered by travel agencies, and printing material is very hard to find. Croatian respondents also rely on online travel guides more than other respondents.

Taking into account all differences in analyzed countries regarding information sources about Banja Luka city brand, the city of Banja Luka should carefully plan the marketing activities and communication channels directed towards particular target groups from different countries.

\section{CONCLUSION}

The increasing use of online marketing tools has particularly significant implications for the travel and tourism industry. They allow sharing of travel-related information among people from different parts of the world, but also made the process of image formation more dynamic [18].

The paper intended to highlight the importance of online information sources for destination promotion, even in case of city destination with still insufficiently developed online marketing. The study confirmed the main assumption that online sources of information are more dominant than traditional ones in case of Banja Luka city destination. This especially refers to the official website of travel destination (Banja Luka), but also social networks such as Facebook and Instagram. This is in accordance with the fact that increasing number of travelers are using the Internet in their travel planning process when they collect first information about destination $[2,20,21,22]$.

The destination's official website serves as a basic tool for providing tourists access to information regarding the destination, which often contributes to the creation of their first impression of the destination. In case of 
Banja Luka city, inadequate optimization of the website can have negative consequences on the overall city image and brand awareness. Word of mouths still represents the major information source, including electronic word of mouths on social media, but also other user-generated content (including reviewing sites such as Tripadvisor). This confirms that respondents more rely on peers' opinion than official destination marketing activities. On the other hand, Facebook and other social media official profiles can be better used by Banja Luka city to target those groups who opt for this kind of information sources. Moreover, the differences between countries in information sources they used in order to get informed about Banja Luka city brand should be considered when creating branding strategies aimed at particular target markets. Due to the dominant role of online information sources the respondents use, the city of Banja Luka should invest more in digital marketing, especially promotion on the website, which is currently not optimized in an adequate way. The same should be done for Social Network Sites such as the official profiles on the Facebook page, Instagram etc. This kind of research should be more often conducted by Tourism organization of Banja Luka as an official subject responsible for tourism promotion and communication with Banja Luka target groups.

\section{ACKNOWLEDGMENT}

This paper is part of the project No. 114-4512539/2016-02 funded by the Provincial Secretariat for Science and Technological Development of the Vojvodina Province, Serbia.

\section{REFERENCES}

[1] Z., Xiang and U. Gretzel, "Role of social media in online travel information search," Tourism Management, vol. 31(2), pp.179-188, 2010.

[2] S. W. Litvin, R. E., Goldsmith, and B. Pan, "Electronic word-of-mouth in hospitality and tourism management", Tourism Management, vol. 29 (3), pp.458-468, 2008.

[3] E., Leivadiotou and D.Markopoulos, "Cyber communities and Electronic Word-of Mouth: The use of Facebook in the promotion of hospitality services", MIBES Transactions, vol.4 (1), pp.138-151, 2010

[4] S., Božić, and T., Jovanović, "Gender, Age, and Education Effects on Travel-Related Behavior: Reports on Facebook" In Consumer Behavior in Tourism and Hospitality Research (pp. 59-80). Emerald Publishing Limited, 2017.
[5] B. A., Sparks, K.K.F., So and G.L. Bradley, "Responding to negative online reviews: The effects of hotel responses on customer inferences of trust and concern", Tourism Management, vol.53, pp.74-85, 2016.

[6] M. R., Jalilvand, and A. Heidari, "Comparing faceto-face and electronic word-of-mouth in destination image formation: The case of Iran", Information Technology and People, vol.30 (4), pp.710-735, 2017.

[7] L.J., Liang, H.C., Choi, and M. Joppe, "Understanding repurchase intention of Airbnb consumers: Perceived authenticity, electronic word-of-mouth, and price sensitivity", Journal of Travel and Tourism Marketing, vol. 35(1), pp. 73-89, 2018.

[8] U., Gretzel, "Consumer generated content - trends and implications for branding", e-Review of Tourism Research, vol. 4 (3), pp. 9-11, 2006

[9] B., Pan, T., MacLaurin, and J.C., Crotts "Travel blogs and their implications for destination marketing", Journal of Travel Research, vol. 46 (1), pp. 35-45, 2007.

[10] S., Molinillo, F., Liébana-Cabanillas, R., AnayaSánchez, and D. Buhalis "DMO online platforms: Image and intention to visit", Tourism Management, vol. 65, pp.116-130, 2018.

[11] S., Pike, and S., Page, "Destination marketing organizations and destination marketing: A narrative analysis of the literature", Tourism Management, vol. 41, pp. 202-227, 2014.

[12] D.,Buhalis, and R. Law, "Progress in information technology and tourism management: 20 years on and 10 years after the Internet e the state of eTourism research", Tourism Management, vol. 29(4), pp. 609-623, 2008.

[13] Cho, Y., Wang, Y., and Fesenmaier, D. R., "Searching for experiences: The web based virtual tour in tourism marketing", Journal of Travel and Tourism Marketing, vol. 12(4), pp. 1-17, 2002.

[14] S., Hays, S. J., Page, and D., Buhalis, "Social media as a destination marketing tool: Its use by national tourism organizations", Current Issues in Tourism, vol. 16(3), pp. 211-239, 2013.

[15] M. M., Mariani, M., Di Felice, and M. Mura, "Facebook as a destination marketing tool: Evidence from Italian regional destination management organizations", Tourism Management, vol. 54, pp. 321-343, 2016.

[16] I., Llodra-Riera, M. P., Martínez-Ruiz, A. I.,JimenezZarco, and A. Izquierdo-Yusta, "A multidimensional analysis of the information sources construct and its relevance for destination image formation". Tourism Management, vol. 48, pp. 319-328, 2015.

[17] "Cities and municipalities of Republic Srpska" Institute of Statistics of Republic Srpska, 2017. Available at: http://www2.rzs.rs.ba/static/uploads/bilteni/ gradovi_i_opstine_republike_srpske/2017/Gradovi_Opstine_Republike_Srpske_2017_WEB.pdf 
[18] J. Hanlan, and Kelly S.. "Image formation, information sources and an iconic Australian tourist destination.” Journal of Vacation Marketing vol.11, (2) pp. 163-177, 2005.

[19] L. Murphy, G.Mascardo, and P. Benckendorff, "Exploring word-of-mouth influences on travel decisions: friends and relatives vs. other travellers." International Journal of Consumer Studies, vol.31 (5), pp.517-527, 2007.

[20] Y., Qiang, R. Law, B. Gu, and W. Chen. “The influence of user-generated content on traveler behavior: An empirical investigation on the effects of e-wordof-mouth to hotel online bookings", Computers in Human behavior vol. 27 (2), pp. 634-639, 2011.
[21] M., Trusov, R. E., Bucklin, and K.Pauwels, "Effects of word-of-mouth versus traditional marketing: findings from an internet social networking site", Journal of marketing, vol. 73(5), pp. 90-102, 2006.

[22] J.K.S. Jacobsen, and A.M., Munar. “Tourist information search and destination choice in a digital age." Tourism management perspectives vol. 1. pp. 39-47, 2012. 